\title{
AN EXAMINATION OF THE IMPLEMENTATIONS OF EDUCATION ARMY DEVELOPMENT (ONE TO FIVE TEAM WORKS) IN HIGH SCHOOLS
}

Miressa Amenu Terfa ${ }^{1}$

${ }^{1}$ Department of English Language and Literature, College of Social Sciences and Humanities, Dambi Dollo University, Dambi Dollo, Ethiopia

*Corresponding Author: Miressa Amenu Terfa

${ }^{1}$ Corresponding Author Email: mirre4boni@gmail.com

Article Received: 18-12-19 Accepted: 25-02-20 Published: 05-03-20

Licensing Details: Author retains the right of this article. The article is distributed under the terms of the Creative Commons Attribution-NonCommercial 4.0 License (http://www.creativecommons.org/licences/by-nc/4.0/) which permits non-commercial use, reproduction and distribution of the work without further permission provided the original work is attributed as specified on the Journal open access page.

\begin{abstract}
The study, tried to find out students' role and perception in implementing one to five team work, examine to what extent school directors facilitate safe environment for the implementation of one to five teamwork and identify the major factors that might hamper the impleentation of one to five teamwork. In order to meet the research goal, descriptive survey design was employed, which involves both methods. In this study, 100 students participated in the research. Thus, descriptive statistics using frequencies and percentages were employed in analyzing the quantitative data and the qualitative data were analyzed qualitatively. The results of the study revealed that students perceived one to five education army development group works positively. However, the followings were found to be the main constraint encountered during one to five team work activities on the findings, it was concluded that one to five teamwork was not properly implemented by the majority of students as it was expected.
\end{abstract}

Keywords: Teamwork, Army Development, Group Work, School, Students, Ethiopia

\section{INTRODUCTION}

It is common these days to hear about education development army, health development army, and reform army etc. in Ethiopia. What all these naming have in common is 'army`. The freedictionary.com defined army as 'a large group of people organized for a specific cause'. What the phrase `specific cause` in this definition refers to in Ethiopia`s context, is being able 
to extricate from poverty. The term 'army' was theoretically taken from military disciple (OEB, 2011). It is believed that as military struggle or work collaboratively by passing through challenges or difficulties to achieve shared goals (to defend enemy or to keep the security of a country), hence, teachers, students, farmers, physicians and others can become more successful in what they do if they work cooperatively rather than working individually. The Ethiopian Ministry of Education started to apply this one- to- five team work in all schools and offices at the beginning of 2003 E.C.

The knowledge base regarding use of instructional grouping (one to five) in the classroom includes findings from research on effective schools, effective teaching, student academic achievement, student perceptions of self and others, student motivation, student attitudes toward school, and student friendships and interactions in the classroom and school. A dominant theme in the research findings is that some types of instructional grouping contribute to more positive academic and affective outcomes for students. Because developing students' attitudes towards learning is considered to be one of the most important issues that should be taken into account while discussing factors affecting the teaching-learning process. For this reason, education development army, one of the most important class activities for developing students' communicative ability, is gradually being applied to teach in our country.

The ultimate goal of one to five education army developments is to enhance all students' achievement, create problem solver, commit and competent citizens who strive to maintain sustainable development in the country (OEB, 2011).

This study provided an opportunity to explore the possibility of the use of one of the techniques of collaborative language teaching (CLT), that is, one to five group formation. One to five requires working together toward a common goal. This type of learning has been called by various names: educational army development, cooperative learning, group work, collaborative learning, collective learning, learning communities, peer teaching, peer learning, or team learning. What they have in common is that they all incorporate one to five or educational army development. This may include students teaching one another, and the teacher teaching the students. More importantly, it means that students are responsible for one another's learning as well as their own knowledge construction and that reaching the goal implies that students have to help each other to understand and learn. In accord with researchbased best practices for improving text-comprehension and reasoning skills, group's discussion practices emphasize acquiring and retrieving multiple meanings from the text, finding the appropriate evidence to support that point of view, and letting students steer the discussion. Most teachers also consider students' participation, collaboration and involvement credit can improve participation (Foster et al., 2009). In addition to these, it cultivates the interpersonal communication. Effective interpersonal communication means that group members communicate with each other on a regular basis, and are careful to ensure that their communication is clear and relevant (Johnson and Johnson, 2000).

School is therefore, the place where teachers and learners come together for interaction and can learn in natural settings. To this end, one to five group formation is a teaching strategy at all levels of education and researchers observed that group based assignments and discussions are a common feature of tertiary education (All Wright \& Bailey, 2004). The effective use of one to fivein can provide valuable learning experience to students and give them the opportunity to practically experience the ideas presented and strengthen their learning. 
One to five or education development army therefore, is aimed at getting the students to take almost full responsibility for working, building knowledge, changing, evolving and of course discussing \&searching improvement together.

In light of this, the purpose of this study is to explore the implementation of educational development army (one to five) during different instructions at the schools and possibly attempts to explore its implementation. And finally, conclusions and recommendations were given on how often different ways of implementing was practiced.

\section{Research questions}

In order to fill the information gap what the whole community has towards education development army the following questions will be answered through this investigation.

1. To what extent do teachers and students persistently implement education development army to build students' team working sprit?

2. How one to five team work or education development armies is basically formed?

3. What do teachers and learners think about the implementation of education development army in teaching - learning process?

\section{Objectives of the Study}

\section{General Objective}

The main objective of this study is to explore the implementation of education development army among high schools.

\section{The Specific Objectives}

The specific objective of this study is :

To realize the implementation of the educational development army in the sample schools.

To identify the appropriate formation of educational army development in the sample schools.

To see how the teachers and students perceive the use of education development army in teaching - learning process.

\section{Significance of the Study}

The findings of the study were expected to give valuable information to serve as a feedback which contributes to improve the practical implementation of education development army in teaching - learning process. Therefore, this research aimed at to explore the present state of education development army is extremely important to find out whether it is applicable or not. The study is of great importance for the teachers teaching at any level and for curriculum designers to develop new books for teaching materials. It was expected that the results of this study revealed important insights for the teachers and curriculum developers or police makers which can become an influencing factor in the subsequent development of new books for students at different levels and for modified teachers training facilities for teachers and students.

\section{RESEARCH DESIGN AND METHODOLOGY}


As the aim of this study is to explore the implementation of Education Army Development in some government schools, descriptive survey type of research was employed, and to explore how often teachers and students employ educational army development and practically use it in the classroom. The design of the research, source of data, sample of the population and sampling techniques, instruments and procedures of data collection, and method of data analysis are stated hereunder.

\section{Research Design}

In this research, descriptive survey which involved both qualitative and quantitative techniques was employed. These techniques are chosen because they could provide information concerning the status of the current implementation of educational army development in the high schools. Therefore, both qualitative and quantitative techniques help the researchers to draw valid conclusions for advance planning of the methods to be adopted for collecting the relevant data and techniques are used during analysis.

\section{Subjects of the study}

The target population of the study was 250 high school students were selected through random sampling techniques, so, a total of 250 respondents were taken for the research. Under this students were the prominent expected subjects. Because, even if there is 1 to 5 groups formation in all sectors of school community, the focus of this research is on learning and teaching process.

Therefore, the researcher decided to choose high schools students for two reasons. The first reason is that the researcher believed that respondents at this grade level have a unique experience with regard to the educational army development at high school because students start to use English to learn other school subjects and discuss every points in English language. The second reason is that the researcher didn't come across a study conducted on exploring the implementation educational army development at high schools; therefore, the researcher felt that the study would fill the gap.

Table 1

\begin{tabular}{l} 
Students' perception on the importance of one to five team works \\
\hline Item \\
SA
\end{tabular}

\begin{tabular}{|c|c|c|c|c|c|c|c|c|c|c|c|c|}
\hline \multirow[t]{2}{*}{ Item } & \multicolumn{2}{|l|}{ SA } & \multicolumn{2}{|l|}{ A } & \multicolumn{2}{|c|}{ UD } & \multicolumn{2}{|c|}{ DA } & \multicolumn{2}{|c|}{ SDA } & \multicolumn{2}{|c|}{ Total } \\
\hline & F & $\%$ & $\mathrm{~F}$ & $\%$ & $\mathrm{~F}$ & $\%$ & $\mathrm{~F}$ & $\%$ & F & $\%$ & $\mathrm{~F}$ & $\%$ \\
\hline $\begin{array}{l}\text { 1. It creates powerful learning } \\
\text { experiences for students }\end{array}$ & 102 & 40.8 & 96 & 34.4 & 22 & 8.8 & 30 & 12 & & & 250 & 100 \\
\hline $\begin{array}{l}\text { 2. It increases students' engagement in } \\
\text { learning }\end{array}$ & 115 & 46 & 80 & 32 & 20 & 8 & 35 & 14 & & & 250 & 100 \\
\hline $\begin{array}{l}\text { 3. It teaches students how to work } \\
\text { with others or to cooperate with others }\end{array}$ & 120 & 48 & 86 & 34.4 & 22 & 8.8 & 22 & 8.8 & & & 250 & 100 \\
\hline $\begin{array}{l}\text { 4. Students develop communication } \\
\text { and teamwork skills. }\end{array}$ & 98 & 39.5 & 102 & 40.8 & 18 & 7.2 & 32 & 20 & & & 250 & 100 \\
\hline $\begin{array}{l}\text { 5. Students hold one another } \\
\text { responsible and accountable. }\end{array}$ & 92 & 36.8 & 100 & 40 & 22 & 8.8 & 36 & 14.4 & & & 250 & 100 \\
\hline 6. It increase psychological intimacy & 123 & 49.2 & 112 & 44.8 & & & 15 & 6 & & & 250 & 100 \\
\hline
\end{tabular}




$\begin{aligned} & \text { 7. It promotes greater contact, trust, } 88 \\ & \text { acceptance and support among } \\ & \text { students of different, social classes, }\end{aligned}$
achievement levels and sexes.

key : SA = strongly agree, $\mathrm{a}=$ agree $\mathrm{ud}=$ undecided $\mathrm{da}=$ disagree $\mathrm{sda}=$ strongly disagree note: strongly agree $=5$ agree $=4$ undecided $=3$, disagree $=2$, strongly disagree $=1$

As shown in table 1, in order to explore students' perception toward the importance one to five team work 7 items were raised. To this effect, the data in the table indicated that the students had positive insight towards the importance of one to five team works in their learning. Regarding item 1, 102(40.8\%) of them strongly agreed and 96(34.4\%) of the respondents agreed on the importance of one to five team work respectively. But 22(8.8\%) of the respondents have no idea and 30(12\%) of the respondents disagreed on the importance of one to five team work respectively. In the same table, the majority of the respondents believed that one to five team increases students' engagement in learning $115(46 \%)$ of them strongly agreed and $80(32 \%)$ of them agreed. However, $20(8 \%)$ of the respondents have no idea and $35(14 \%)$ of the respondents disagreed on the idea of item 2 . The respondents also affirmatively replied one to five team teaches students how to work with others or to cooperate with others and respect of others opinions among students $120(48 \%)$ of them strongly agreed and $86(34.4 \%)$ of them agreed.

On the other hand, the table shows that more than half of the respondents believed that one to five team work has a positive effects on students' academic achievement 98(39.5\%) of them strongly agree and 102(40.8\%) them agreed).

Additionally, the table indicates that with the exception of few respondents all recognized that students develop communication and teamwork skills.92(36.5\% of them strongly agreed and $100(40 \%)$ of them agreed respectively).

Majority of the respondents confirmed that as one to five team work is very important in building students' psychological intimacy $123(49.2 \%)$ of them strongly agreed and $112(44.8 \%)$ of them agreed).

Finally, the table reveals that a large number of participants thought that one to five team work promotes greater contact, trust, acceptance and support among students of different, social classes, achievement levels and sexes. 88(35.2\%) of them strongly agreed and 105(42\%) of them agreed).

To sum up, the aggregate responses of the participants indicated that most of them have a favorable attitude towards one to five team work.

Table 2.

Factors that affect one to five team work implementation Responses to factors Related to students.

\begin{tabular}{|c|c|c|c|c|c|c|c|c|c|c|c|}
\hline & \multicolumn{2}{|l|}{ SA } & \multicolumn{2}{|l|}{ AG } & \multicolumn{2}{|c|}{ UD } & \multicolumn{2}{|c|}{ DA } & \multicolumn{2}{|c|}{ SDA } & \multirow[t]{2}{*}{ Total } \\
\hline & $\mathrm{F}$ & $\%$ & $\mathrm{~F}$ & $\%$ & $\mathrm{~F}$ & $\%$ & $\mathrm{~F}$ & $\%$ & $\mathrm{~F}$ & $\%$ & \\
\hline $\begin{array}{l}\text { 1. Reluctance to work in one to five } \\
\text { team }\end{array}$ & 108 & 43.2 & 88 & 35.2 & & & 40 & 16 & 14 & 5.6 & 100 \\
\hline $\begin{array}{l}\text { 2. Lack of understanding about the } \\
\text { importance of one to five team } \\
\text { work }\end{array}$ & 152 & 60.8 & 90 & 36 & 8 & 3.2 & & & & & 100 \\
\hline $\begin{array}{l}\text { 3. the way the one to five team is } \\
\text { formed }\end{array}$ & 54 & 21.6 & 42 & 16.8 & 24 & 9.6 & 96 & 38.4 & 34 & 13.6 & 100 \\
\hline 4. Domination of active learners & 122 & 48.8 & 102 & 40.8 & & & 26 & 10.4 & & & 100 \\
\hline
\end{tabular}




\begin{tabular}{llllllllllllll}
\hline 5. Insufficient time given for the task & 160 & 64 & 70 & 28 & & 20 & 8 & & 100 \\
6. Lack of interest to share knowledge & 97 & 38.8 & 87 & 34.8 & 22 & 8.8 & 44 & 17.6 & 10 & 4 & 100 \\
with others
\end{tabular}

Regarding reluctance to work in one to five team, majority of the respondents confirmed as it was a factor that hindered the implementation of one to five team work. 108(43.2\%) strongly agreed, and $88(35.2 \%)$ agreed on the idea of reluctance respectively. And the rest, $40(16 \%)$ and $14(5.6 \%)$ of the respondents replied that they disagreed and strongly disagree respectively. On the other hand, majority of the respondents $152(60.8 \%)$ and $90(36 \%)$ of the respondents responded that they didn't understand the importance of one to five team work as it is excepted. So, this could be a major problem for its implementation and students did not care about. Only $8(3.2 \%)$ of the respondents disagreed on the idea which mean that lack of knowledge about the importance of one to five team work has no impact on its implementation.

About 54(21.6\%) and 42(16.8\%) of the respondents show the way they could be formed in one to five team work was one factor for the implementation of one to five team work. But the majority of the respondents, $96(38.8 \%)$ confirmed that as the way of forming one to five team work has no impact on it implementation. Similarly, 24(9.6\%), and 34(13.6\%) of the respondents also confirmed that the way of forming one to five team work has no impact on it implementation.

Regarding item 4, all most all of the respondents responded than domination of active learner is one of the major factors for one to five implementations. To this end, 112(48.8\%) and $102(40.8 \%)$ of them strongly agreed and agreed on the idea of active learners domination during one to five team work. This confirms that the members of the team were not actively participated in the activity. Regarding this, only 26(10.4\%) of the respondents disagreed. Therefore, the domination of active learners in the team work was proved to be one of the constraints.

Similarly, $160(64 \%)$ and $70(28 \%)$ of the respondents revealed that the major factor which hinder the implementation of one to five team work was lack of time. This indicates that one to five team work didn't get due attention.

Lack of interest to share knowledge with others was confirmed by $97(38.8 \%)$, and $87(34.8 \%)$ of the respondents since they strongly agreed and agreed respectively to show that lack of interest to share knowledge with others is one factor that hinder the implementation of one to five team. This could be improved if one to five team work activities are graded. $22(8.8 \%)$ of the respondents have no idea and 44(17.6) and 10(4\%) of the respondents revealed that lack of interest to share knowledge with others has no impact on the implementation of one to five team work.

\section{Conclusions}

On the basis of the preceding findings, conclusions about the study have been drawn. One of the most recent trends in collaborative learning appears to be the use of one to five team work in Ethiopian context.

Although the importance of one to five team works is perceived positively by teachers and school directors, the practice and the implementation of one to five team work in the sample schools were still found to unsatisfactory. Even if students perceived one to five team work activities positively, they were not given any orientation on the importance of it and the 
responsibilities of each member in the team was not clearly explained at the beginning of the school year and team formation.

The study showed that there is low safe environment where members of one-to-five teachers' teamwork can openly discuss. The questionnaire result of the students, homeroom teachers and school directors and the interview also shows the school environment is not conducive as expected for team work. On the top of this, insufficient time and none grading for one to five team work were critically affected the implementation of one to five team work.

\section{References}

Foncha, J.W. (2013). A Selective Investigation of the University of the Western Cape's Students and Teachers Attempts at Intercultural Communication: Exploring the Connections.

Oromia Education Bureau. (2003/2011). Directive of Development Army and Works of Education Development Army. Commercial Printing Enterprise: Addis Ababa.

Oromia Education Bureau. (2004/2012). Gemgema of Education Work of 2004/2012. Addis Ababa. Unpublished.

Oromia Education Bureau. (2005/2013). Gemgema of Education Work of 2004/2012. Addis Ababa.Un published

Solomon W. (2010). A modern teaching methods manual for primary and secondary schools people in need (pin) is an international ngo based in Czech Republic 